\title{
Gender Discrimination in Media as Workplace: A Study of Media Environment in Sindh
}

\author{
Fazal Hussain \\ Department of Mass-Communication \\ Federal Urdu University Karachi
}

\begin{abstract}
This study explores media industry in the province of Sindh, Pakistan for gender discrimination. It is generally believed that gender discrimination is based on patriarchal conception of society and is greatly rooted in culture whereas the economical and social models are also responsible for inculcating discrimination based on gender. But the changing patterns of social institutions and the transforming trends in financial designs are determining new standards and definitions. Although the feminist theorists and feminist's movements have played magnificent role for the eradication of gender discrimination but the mindsets are still to be changed because they are hardened by socialization and cemented by customs, culture and religion for centuries. This research attempts to consult working journalists for whether they have faced, or facing, or observed, or observing discrimination within the media theatre, or the field is free of these curses. This study employs survey technique using a close ended questionnaire constructed under Guttmann Scale. It also conducts face-to- face interviews with senior journalists in Karachi, Hyderabad and Larkana implanting snowball method to deeply explore the media environment in Sindh for gender discrimination. On the basis of its findings, this research offers some implications and suggestions for policy framing and future research.
\end{abstract}

Keywords: Gender Discrimination, Women Journalist, Media, Threats to Journalists, Culture, Social Norms and Values, Economical Model of Society.

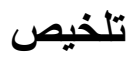

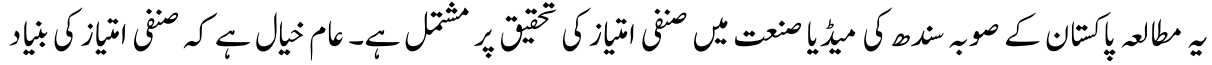

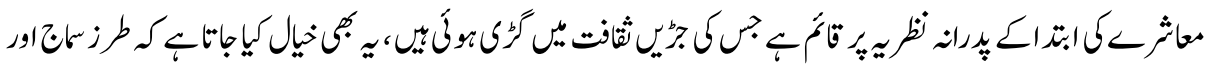

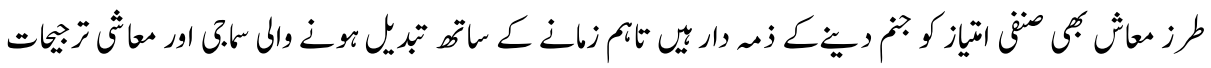

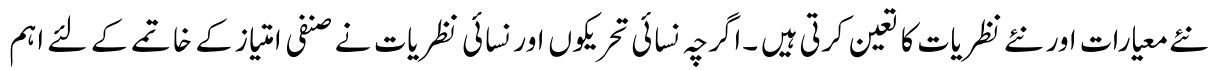

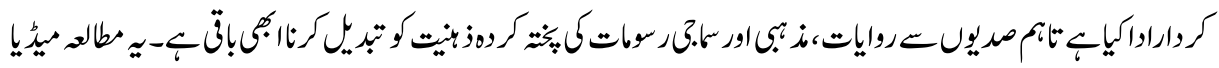

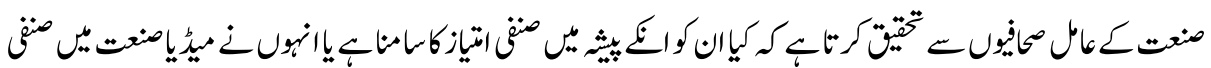

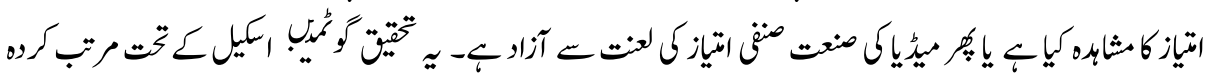




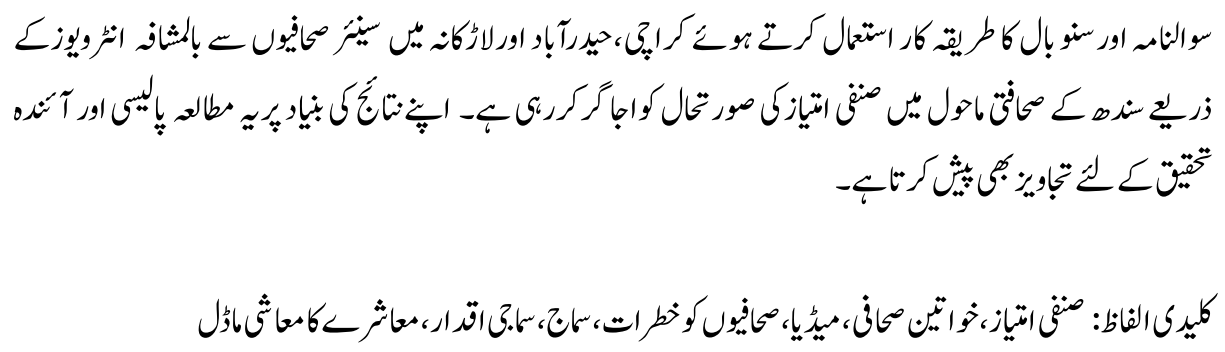

\section{Introduction}

Discrimination in any form is not permissible by rules in any country or society in the world but it has been practiced in all ages and in each society or state and region of the globe. Discrimination on the basis of race as ethnocentrism, on the basis of xenophobia as a fear to foreigners, on the basis of religion, on the basis of sexual orientation, on the basis of disability and on the basis of gender, exists everywhere with little difference in its magnitude, impacts and approaches (Adu-Oppong \& Aurther, 2015).

The gender discrimination is centuries old and deep rooted because it has been practiced and recognized as a part of cultural norms and values (Morna, 2002). This unjust practice was being justified on the ground: woman as a wife to serve her husband and as a mother to nurture her children and this was apparently accepted by them as a social structure and an assigned role in the nuclear family institution. This stereotype approach towards women still exit with full effect in undeveloped and less educated parts in each and every society and state all over the world but less and in some case not in practice in the developed and educated societies. Historical developments in economical and social models reveal that the gender based discrimination is vitally linked with economical needs. When interdependency in the institution of family was strong, the traditional traits in societies were related to power: typical activities of men were characterized as brave, strong, productive and public oriented whereas the women's were characterized as powerless, dependant, caring, passive and family oriented. The biological structure and physical capacities for the painstaking and rigorous labor in the field of production and in the wake of self or family protection were favoring this stereotyping but after the industrial revolution in $18^{\text {th }}$ century and renaissance in thoughts, this stereotype was sensed and pinpointed (Hearn \& Parkin, 1987). Dr. Arifa Fareed (2000) declares that modernism gave way to individualism that lessened the interdependence while the postmodernism as communicational revolution empowered the individuals. Democratization of state systems and globalization implanted developments in educational level and it introduced changes in social and cultural patterns. This process empowered the women and institutionalized gender interests. At the same time, the economical model of patented societies, where man was the sole provider, had to change because that was becoming difficult to earn for the whole family and the cultural clutches were loosened 
and woman was allowed to financially support the family. This change in social structure needed skill developments and education. And the trend to educate the women prevailed. This picture, we can see in the difference in ratio of female education levels and women's participation in economy enhancing institutions.

The Universal Declaration of Human Right (UDHR), the International Convention on the Elimination of All Form of Racial Discrimination (CERD), the Committee on the Elimination of All Form of Discrimination against Women (CEDAW) and constitutions of all the democratic states denounce discrimination on the basis of gender and acknowledge the gender equality. These trend growths encouraged social activists and gave birth to Non Governmental Organizations (NGOs) to inculcate awareness against gender discrimination and to initiate and support discrimination shedding measures. As a result most of the countries of the world adopted affirmative discrimination: deliberately favoring the groups who have experienced pervasive discrimination for a long time. The improvement in the name of Quota tries to compensate but still the ratio and magnitude is negotiable. In Pakistan like other developing countries gender discrimination exist in all its dimensions but its eroding has begun that needs to be enhanced by empowering women.

Direct gender discrimination has been largely addressed and measures on national and international levels has been taken to be eradicated but the indirect gender discrimination in the shape of policies or measures, which may appear neutral but systematically put woman at disadvantage compared to man, are still to be searched, be pinpointed and to be calculated statistically for proper and directional policy oriented suggestions. This research paper is aimed to search this trend in the media in Sindh.

Gender differences in the labor market have been persistent overtime all over the world; women's participation rate has generally lagged behind the rate for men. The base is the commitment of women to household activities and the media market in Pakistan is no exception. This study attempts to find out the quantitative position of gender discrimination, consulting working journalists in the province of Sindh, Pakistan.

The Global Media Monitoring Project's report (2010-2015) reveals that the participation of women in electronic and print media is only $24 \%$ all over the world whereas the situation in Pakistan is more fading where cultural norms and values are not in the favor of women's participation in industries like the press.

Reports of international organizations preparing press freedom indices are placing Pakistan as not free or partially free indicating that the press and journalists are under target and are exposed to threats. In such a scenario, women journalists are more exposed to pressure and threats from both external and internal factors. This study tries to explore the media landscape for external as well internal threats to journalists in Sindh. 


\section{Literature Review}

According to the Declaration on the Elimination of Violence against Women "any act of violence based on gender that results in physical, sexual, or psychological harm or suffering to women, including threats of such actions, coercion or arbitrary deprivation of liberty, whether occurring in public or privately" (UN 1994), is Gender Discrimination. This definition was ratified by the General Assembly of the United Nations.

In the same pattern, Convention on the Elimination of All Forms of Discrimination against Women (CEDAW, 1979) also defines and addresses gender-based violations against women and that was also adopted by the General Assembly of the United Nations.

But according to senior journalist Sheher Bano, this definition determines the apparent features of discrimination based on gender whereas the hidden or indirect violence in the wake of gender based discrimination is also important and also needs to be addressed (Bano, 2018).

Similarly, diversity in the existence and patronage of gender discrimination is explored by Jayachandran (2015) who concludes that gender gap in several domains exist largely in developing countries. But the sectarian shift away from agriculture towards services, the technological advances, which reduce time needed for house hold and the decline in the risk of child bearing increase women's participation in labor force, which in return enhance status of women in the economical and social model. But still women are treated unequally and less value is placed on their lives because of their gender. Women's differential access to power and control of resources is central to this discrimination in all institutions including media (Reeves \& Baden, 2000).

It is very important to note that participation of women in media is comparatively less in all the countries. Wood (n.d) quotes Lichter \& Rothman who concluded in 1986 that lack of women in the American media was parallel by the scarcity of women in charge of media and only $5 \%$ of television writers, executives, and producers were women but twothirds of journalism graduates were women. Same were the findings of a survey (women in Media, 1988) which calculated that women made up less than $2 \%$ of those in management of newspapers and only about $5 \%$ of newspapers publishers. At the time, participation and position of women in media in Pakistan portray the same situation but the circumstances are changing and strive for positive discrimination can be observed in the media landscape of the country. In this regard the Young Publishers Committee and Women Publishers Committee of All Pakistan Newspapers Society (APNS) is the encouraging attempt to boast the participation of women in media industary. 
More hoping are the circumstances about the women's participation in media as the GMMP (2010) affirms that percentage of news stories in print media by female journalists has increased since 2005 to $35 \%$ while that enhancement is up to $40 \%$ in electronic media. But the report shows that female journalists are limited to soft beats like arts, entertainment and lifestyle coverage (Sharda, 2014). The report also portrays the growing participation of female journalists in media in Pakistan.

Contrarily, the GMMP (2015) Findings reveal that women make up about $50 \%$ of the general population but only $24 \%$ of the persons heard, read about or seen in newspaper's, television's and radio's news all over the world. According to the report participation of women as journalists in print media is $3 \%$, in radio $33 \%$ while in TV that is $64 \%$ in Pakistan. Under the table of gender representation in the news, ratio of females is $36 \%$ while that of males is $64 \%$ whereas in the category of overall reporters the ratio of females is $16 \%$ and that of males is $84 \%$ in the part of Pakistan. These statistics are not encouraging but the category of presenters, female's participation in radio is $100 \%$, in TV $69 \%$ and the overall is $86 \%$ while that of males is $14 \%$ in Pakistan. The situation here is hoping and reveals bright future for women in media of the state.

The economical aspect of gender discrimination is indicated by the World Survey (2009) on the role of woman in development where it concludes that women's economic empowerment requires integrated approach to development, focused on genderresponsive employment promotion and informed by interdependence between economic and social development. The report finds that women's unequal access to resources and their persistent responsibility for unpaid domestic job curtail their productivity and restrict their productivity to respond to new economic opportunities (W.S, 2009).

Similarly, Abbas, Hameed \& Waheed (2011) explores the economical impacts of discrimination based on gender, he declares that the productivity and performance of an organization is affected by the performance of employees and the performance of the employees is affected by gender discrimination. This generalization was found after a survey conducted in telecom sector in Pakistan but the media market is no exemption.

Hence, improvement in educational level gradually declines the difference between male and female employment rates and that as a result this move is minimizing discrimination based on gender because the productive placement in family institution is changing the behavioral approaches (Adu-Oppong \& Arthur, 2015).

But, King (2002) denotes that there are global patterns to inequality between woman and men. She further explores that women tend to suffer violence at the hands of their intimate partners more often than men. Women's participation in decision making structures is far behind men and this positioning of gender based phenomenon create 
imparity in population and family earning structure which leads to discrimination and gender stereotyping. These issues need to be addressed in efforts to promote gender equality.

Such as, women's participation in productivity can be enhanced by education and proper skill development trainings (Georgellis \& Wall, 2004). Same can be achieved by improving family health and life standards. Women can be brought equal to men by measures that make them capable to secure equal share in productivities and in family earnings (Le-Anth, 2000).

This research is aimed to calculate gender discrimination in the media landscape in the province of Sindh Pakistan. Two hypotheses are devised to test and generalize the existence of gender discrimination and the content of threat in media.

\section{Hypothesis No 1:}

Gender discrimination exists in media in the province of Sindh, Pakistan.

\section{Hypothesis No 2:}

Journalists are facing threats in the field while performing their professional duties in Sindh.

\section{Importance of the Study}

Gender discrimination is largely addressed on the national and international stage and a lot of literature and research reports are compiled and published but the specific study of gender discrimination in media and its relation with threats has not been ever made. This research explores the media in Sindh for the variables (gender discrimination \& threats) consulting the component part (journalists) and tries to generalize the concept by quantification the perception.

\section{Social and Economical Models, a Gender Stereotyping}

Basically, the Pakistani society is heterogenic in its nature with great variety of historic, cultural, lingual and geographical persona and back ground but some common features linked with eastern cultural traits are also nourishing here. The agricultural mood of productivity, rural dominance in population, strict cultural ties, fundamentalist theological approaches, strong ethnic norms, weak democratization in public and private institutions, no trend of institutionalization, warm and dry atmosphere, strengthened by centuries unperturbed practices of man dominancy in all sectors of family and social life, 
recognized by the South Asian Chapter of Islam, have reckoned the gender stereotyping in the society as a common trait.

The patriarchal social and economical systems of the region accumulate decision making powers in the hands of men and the ethnic and religious definitions of Ezzat (social respect) and Ghairat (honor) are cementing the stereotyping of gender. The position of man as a provider in the family economical model dominates him over female component while the theological and social norms and values and teachings confine women to live in veil and surrounded by walls. Although the rate of participation of women (72\%) labor force is more than men $(28 \%)$ in the agriculture sector in Pakistan (Zaheer, Hussain \& Nadeemullah, 2016), but the decision making power rests in the hands of men as patented social trait because women are used only to work like a machine and without a share in the output rather eating and wearing.

Low educational level, no skill development training, no public participation and less awareness of women's rights in the strictly men controlled society depreciate the position of women. The economical heterogeneity of Pakistani labor market and rural mood of productivity place the women on dominant position as provider in some areas in the Sindh Province in specific communities (Abbasi 2018) but as social pattern and low cultural position stop her way in the main stream economical and social model, the women can't cash her position properly.

\section{Gender Discrimination and its Roots}

Only thoughts and philosophies can't deep root the biases rather they need material grounds to implant and nourish and live persistently strong. Gender discrimination here in Pakistani society has both material basis and philosophical reckonings. The patriarchal orientation of society and hard labor based productivity market provides material support to stereotyping gender bias on one hand and weak rule of law, high class distinctions, less social awareness of the neo-world order and high sexuality trend endanger the female participation in main stream social and labor market.

The physically weak body is not capable to protect a woman from physical attacks while there is no trend of sporting or athletic or acrobatic training in the society to make her combating whereas the rule of law is weak and the law and order situation in not well. This situation negatively affects the participation of women in productivity market and as a result they remain on low position exposed to discrimination.

Discriminative low wages in economic market is also the base of low productivity position in the family financial model. Women and men working on the same position get different salary package seems very illogical but this discrimination exists even in media 
industry which is believed to abolish discrimination and insure rule of law performing its duty as a watch-dog (Bano 2018).

Old- age-Son Support concept is also a material base for gender discrimination prevailing in the Pakistani society. The family pattern is male centered where parents have to live with sons while daughters leave their parent's homes after they got married. The traditional heredity division of lands and other non-transferrable assets also support the formation of patriarchal approach which makes the gender discrimination applicable. Due to patent family structure and lack of old-age governmental support, the discriminative approach is justified.

The high fertility rate, large family, low health education and health services, no trend of technology use and congested household labor enslave women in the house. This pattern of life and lively hood assign them the house hold oriented trait that leads to discrimination (Miller, 2010).

Male orientation and hard timing rule in the services market in Pakistan also minimize opportunities for female to participate in earning arena and to get strong her position as a component part of family structure. Due to family hurdles, security risks, sexuality, harassments and other factors, chances for women to work in night times in offices are reduced. The day time jobs are mostly occupied by male part of productivity market and as a result women are deprived to improve their status as providers.

Article 25 under $24^{\text {th }}$ amendment as enacted on December 24, 2017 states; (1) All the citizens are equal before law and are entitled to equal protection of law. (2) There shall be no discrimination on the basis of sex and (3) Nothing in this Article shall prevent the state from making any special provision for the protection of women and children. As an affirmative discrimination, special seats for women were increased to 60 in the National Assembly for the expected general election 2018. But in spite of all the constitutional protection and support gender based discrimination exists in the society and in all institutions of public and private sectors. Report issued by Freedom House for 2017 finds; Constitutional guarantees of freedom of religion and protection of minorities have not provided effective checks to discriminatory legislation, social prejudice, and sectarian violence in Pakistan. The repot puts Pakistan in the category as Not Free state regarding the freedom of press (FH, 2018).

\section{Gender Discrimination in Media: Global Context}

Gender discrimination persists at the fundamental level of employment in news organizations. Matias \& Wallach (2015) find that the percentage of females in US newsrooms has remained at $37 \%$ in the years 2001-2015. According to UNESCO 
documents, women perform two-third of the world's work but they earn only one-third of the income. The documents further sate that women comprise two-third of the world's illiterates and own less than one-hundredth of property (UNESCO, 2009).

The Global Media Monitoring Project's (GMMP, 2015) report shows the empirical of the women's proportion and participation in international media market. The survey finds that less than twenty four percent of the employees of media are female. The report further shows that the representation of women journalists in politics and government based stories is only four percent and that in economical stories is one percent. This trend shows that the female's participation in media both electronic and print is affected by the discriminative approach based on gender.

Eventual stories of working journalists compiled under the title "Going it alone: More freelancer means less support, greater danger" by Committee to Protect Journalists (CPJ) reveals that working alone is dangerous and that situation for women journalists is the most dangerous job to do (CPJ, 2018).

\section{Gender Discrimination in Media: Pakistan Context}

Ownership: As a legacy of colonial era, media in Pakistan has been dominated by men. The ownership structure and its history reveals that the proportion of women is lesser and only family journals and cooking tabloids are owned by females but no main stream media enterprise is declared in the name of a woman. This picture of the media industry shows a discriminative trend based on the gender (APNS).

Editorship: Although the Sherry Reham and Maliha Lodhi are the great names in the lists of the editors of newspapers but the number is much lesser to compare to that of males. The media is largely dominated by male editors (Bano, 2018).

Reporter: Comparatively more females' reporters are seen on the sphere of electronic media where as the print media recruits lesser number but as a ratio with males, the number of female reporters is far lesser than that of males (Faran, 2018).

Photographers/camera persons: No female photographer or camera operator is there in media in Sindh (Nasir, 2018). The working conditions as photographer or camera operator are not in the favor of female journalists.

Representation in Press Club: The ratio of representation of women journals in the executive bodies of press clubs is very low in the province of Sindh. There is only one female journalist as member of the governing body of Karachi press club whereas the history shows no female journalist on the post of president or secretary (KPC, 2018). The 
situation in Hyderabad, Larkana, Jacobabad and other districts is not hoping where no women journalist is present on any post on the executive level (Sheikh; Shahid; Durani, 2018).

\section{Duty Timings and Hindrances for Women Journalists}

The structure and working procedure of media is not in the favor of women journalists (Khanzada, 2018). The working of news media is divided into indoor office duty as editor, news editor, sub editor [Print media], director news, copy editor, copy writer, producer and anchor [Electronic Media] and outdoor field duty as chief reporter, reporter, photographer and camera person.

The filed duty is relatively hard laborious and largely exposed to threats and pressures. The outdoor duty increases problems for women journalists as they are already confronting the gender discrimination prevailed in the society and threats and pressure linked with profession multiply the barriers.

The office duty as indoor job is better but the timing frame reduces opportunities for women journalists. The usual and main desk work in print media starts in the evening and papers are downed after 2.00AM. The number of special editions is less and most of the local news papers publish no special edition. The only day transmission of electronic media and hard competition and lesser education trend in female make the entry point narrow for women as journalists in the industry (Sofi, 2018).

\section{Discriminative Attitude of Co-Workers}

Journalists are part of the society and are generally affected by the stereotype perception regarding gender. The male co-worker's attitude in media is governed by the same discriminative mood and that the situation perturbs women journalists in their offices (Bano; Isbah, 2018).

\section{External Threats to Journalists}

Media in Sindh has always remained under threats under pressure. Press in big cities like Karachi and Hyderabad is freer than that in small towns of Sindh (Latif, 2018) but journalists in small towns are exposed to threats and suffer more than in large cities (Sheikh, 2018)because law and order situation in big cities is better than that in the small towns. Journalists face double pressure for their journalistic work in small towns, on one hand the institutions ask for filing reports while on the other hand, the interests groups threaten journalists and demand them not to cover specific events and news stories (Durani, 2018). This scenario on the stage of media multiply threats for female journalists 
because they are more exposed to pressure and threats and they have to combat more threats based on stereotyping perception of gender discrimination.

\section{Methodology}

This paper consists of quantitative research technique. Survey was used as the tool to find the content of gender discrimination and threats in the media in Sindh, Pakistan. One hundred and twenty questionnaires were personally distributed in working journalists in Karachi, Hyderabad and Larkana using snowball method. One hundred were filled and returned by the respondents. The data was statically analyzed and presented in tables and pie charts.

Unstructured interviews were also managed with senior journalists to test the hypothesis. Twelve senior journalists and post bearers of journalist's organizations and unions including four women journalists were interviewed in Karachi, Hyderabad and Larkana. All the interviews were tape recorded after a prior consent and were transcribed.

Universe of the study is the media landscape of Sindh. As there is no study or document present that shows exact number of journalists so a sample of 120 journalists was selected as a sample of the population including male and female journalists. Directional questionnaire was distributed in twenty five women and 95 male journalists. The ratio (1:4) was deliberately enacted to get generalized results based on the proportion of male and female participation in the profession as the GMMP (2015) findings affirm.

\section{Sampling}

Non probability sampling method i.e. the Snowball was adopted as that is suggested by Vogt (1999) for the type of research where the population is undefined. Snowball technique provides referral chain that links characteristics make easy to reach the ground realities (Vogt, 1999).

The population of journalists in Sindh is undefined and no exact data is present in this respect, so that the study used the snowball method and consulted working journalists for the collection of data regarding discriminations and threats to journalists in the province.

\section{Measuring Scale}

This research adopts the Guttmann Scale. The scale facilitates the respondents with "Yes" and "No" choices as affirmative and negative. Kumar (2016) suggests the Cumulative (Guttmann) scale for one dimensional response. This scale is suitable with no confusion to get and generalize the results (Kumar et el., 2016). 


\section{Data Presentation and Discussion}

The study distributed 120 questionnaires among working journalists directed to calculate the variable of the research. After six working days questionnaires were collected and 95 were found complete in all respects. Out of 95 questionnaires 82 were filled and returned by male while 13 out of 25 were filled by female respondents. Data of 95 questionnaires was statistically analyzed and presented in frequency tables and pie charts as under.

\section{Confession of Discrimination in Media as Work Place}

The following table summarizes results of sampled journalists about discriminations in media as work place. The figure illustrates the results when journalists were asked whether they face discrimination in their working places.

\begin{tabular}{|c|c|}
\hline \multicolumn{2}{|c|}{ Table \& figure 1 } \\
\hline $\begin{array}{c}\text { Do you face discrimination in } \\
\text { media as workplace? }\end{array}$ \\
\hline \multicolumn{2}{|c|}{ Frequency } \\
\hline Yes & 19 \\
\hline No & 68 \\
\hline \multicolumn{2}{|c|}{$\mathrm{N}=87$} \\
\hline \multicolumn{2}{|c|}{ No answer $=8$} \\
\hline \multicolumn{2}{|c|}{ Total=95 } \\
\hline
\end{tabular}

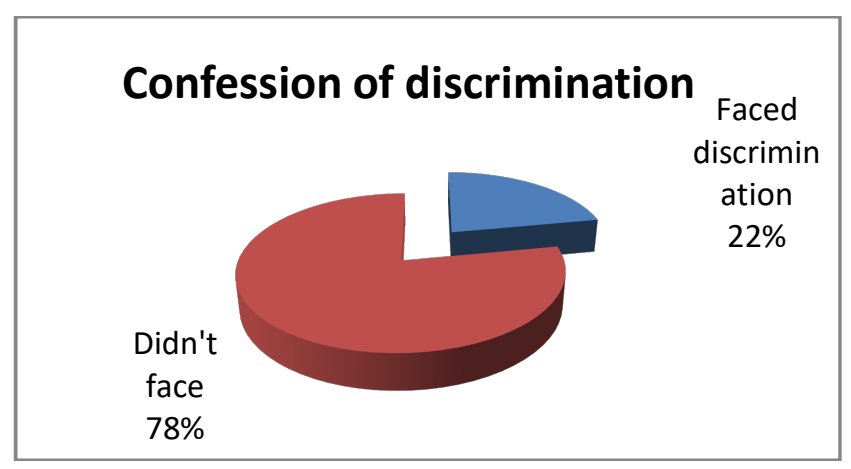

Interpretation: Table \& Figure 1 reveals that discrimination exists in media in the province of Sindh. Twenty two percent of the respondents confessed discrimination while seventy eight percent of the respondents say, they has not confronted with the curse of discrimination in their field of work. Although $22 \%$ is lesser but it indicates the very existence of discrimination which confirms that media is not free of the stereotyping approach.

\section{Perceptions about the Existence of Discrimination}

The following table summarizes perceptions of sampled journalists about the presence of discrimination in media as workplace. The figure illustrates the results when journalists were asked where they have observed discriminations in media as workplace. 


\begin{tabular}{|c|c|}
\hline \multicolumn{2}{|c|}{ Table \& figure 2 } \\
\hline $\begin{array}{c}\text { Do you observe discrimination in } \\
\text { media as work place? }\end{array}$ \\
\hline \multicolumn{2}{|c|}{ Frequency } \\
\hline Yes & 34 \\
\hline No & 53 \\
\hline \multicolumn{2}{|c|}{ No answer $=87$} \\
\hline \multicolumn{2}{|c|}{ Total=95 } \\
\hline
\end{tabular}

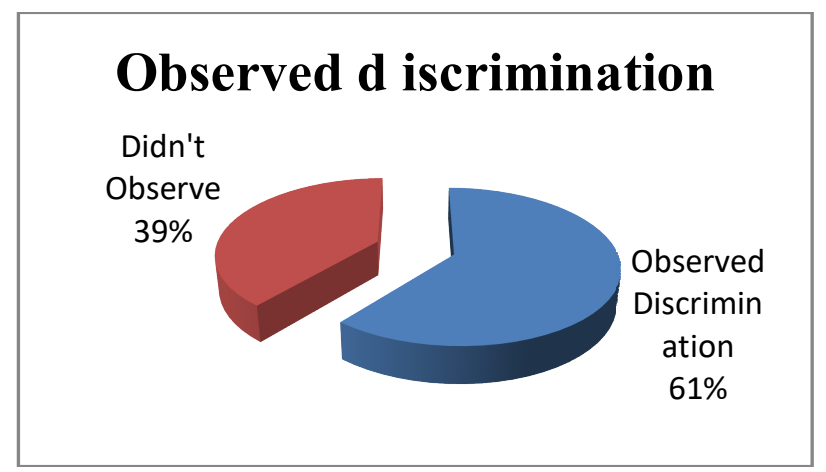

Interpretation: Table \& Figure 2 shows that $39 \%$ of the respondents have observed discrimination in media while $61 \%$ have not witnessed discrimination in their field. The statistics reveal the presence of discrimination in media in the province of Sindh. The situation is alarming and indicates a trend of inequality.

\section{Levels of Discrimination in Media as Workplace}

The following table describes perceptions of sampled journalists about discriminations in media as workplace. The figure indicates the results when journalists were asked about the types of discriminations they have faced or observed in the line of their duty and field.

\begin{tabular}{|c|c|}
\hline \multicolumn{2}{|c|}{ Table \& figure 3} \\
\hline Discriminations & Frequency \\
\hline Gender & 26 \\
\hline Religion & 8 \\
\hline language & 37 \\
\hline Political thoughts & 20 \\
\hline Economical status & 5 \\
\hline Social status & 5 \\
\hline Education & 5 \\
\hline Experience/skills & 10 \\
\hline \multicolumn{2}{|c|}{ Total $=116$} \\
\hline \multicolumn{2}{|c|}{ No answer $=8$} \\
\hline
\end{tabular}

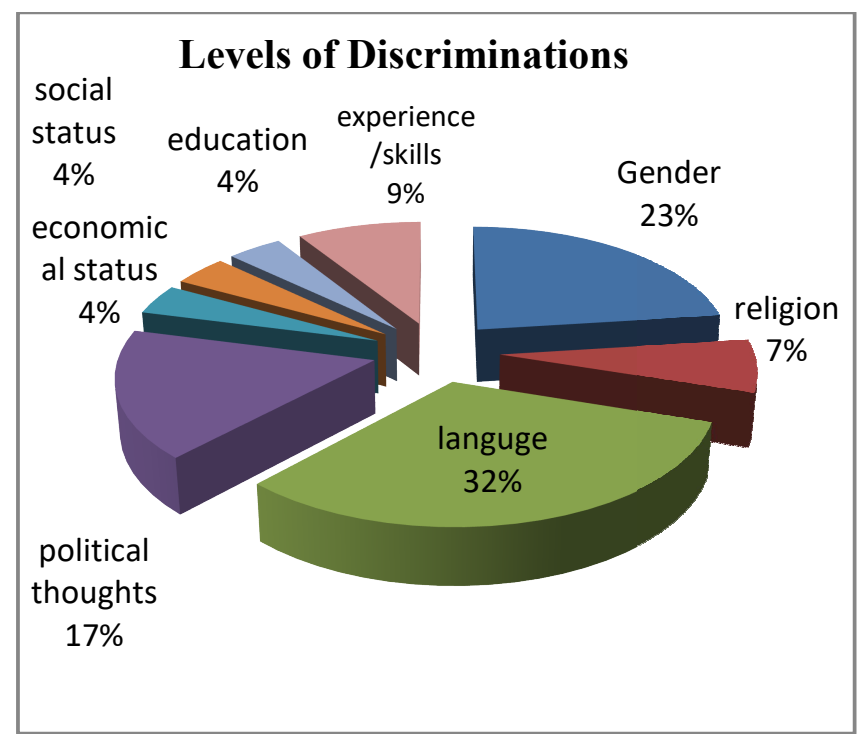

Interpretation: Table \& Figure 3 indicates that discrimination based language tops with $32 \%$, seconded by gender discrimination with $23 \%$ share. Discrimination on the basis of political thoughts is on the third position with $17 \%$ following by skill based discrimination, religion based and the on the basis of economical, social status and 
educational level, $9 \%, 7 \%$, and $4 \%$ respectively. Although $32 \%$ of the respondents affirms the lingual based discrimination and that is alarming in the field as a prevailing racial discrimination but the statistics also confirm the Hypothesis of the study as $23 \%$ of the respondents confirms the existences of gender discrimination in media in the province of Sindh, Pakistan and that the second highest score of discrimination in the population under study.

\section{Threats to Journalists}

The study explores the media environment in the Sindh Province of Pakistan for threats to working journalists. The study defines the threats on the physiology of threatening. In this context "Threats" are acts, verbal, phonic or by messages direct or indirect terrifying and compelling a journalist to follow the specified lines in connection to courage of media content. The study indicates the results of survey regarding the presence of threats in the province.

\section{Confessions of Threats}

The following table summarizes the confessions of sampled journalists about the threats they have faced in the line of their duties. The Figure illustrates the results when journalists were asked whether they have faced threats in the line of their duties.

\begin{tabular}{|c|c|}
\hline \multicolumn{2}{|c|}{ Table \& figure 4} \\
\hline $\begin{array}{c}\text { Have you faced any threat in the line of } \\
\text { your professional duties? }\end{array}$ \\
\hline \multicolumn{2}{|c|}{ Frequency } \\
\hline Yes & 37 \\
\hline No & 58 \\
\hline \multicolumn{2}{|c|}{ Total $=95$} \\
\hline
\end{tabular}

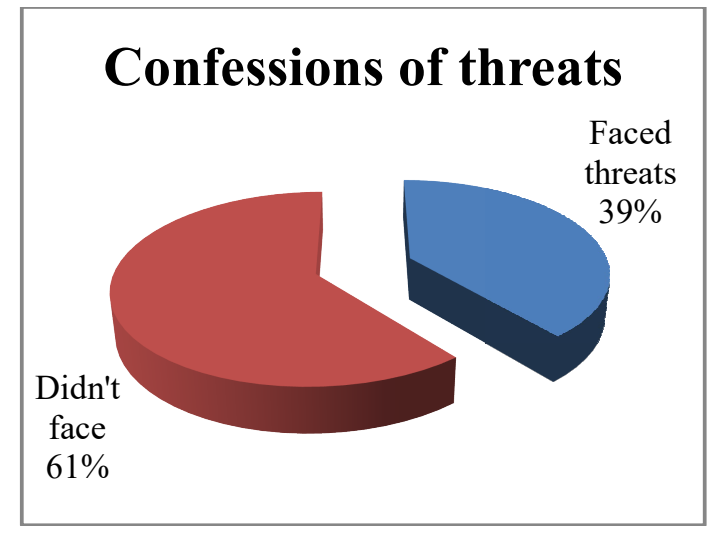

Interpretation: Table \& Figure 4 illustrates that the content of threat exists in media in Sindh. Although more (60\%) affirmed that they have not confronted with threats for their journalist work $39 \%$ of the respondents confirm that they have faced threats for their profession and that indicate the presences of threat in the field and that verify the second Hypothesis of the study. 


\section{Confession of Physical Harassments}

The following table sums up the confessions of sampled journalists about the physical harassments they have faced in the lines of their professional duties. The figure demonstrates the results when journalists were asked where they have faced any physical harassment in the line of their duties.

\begin{tabular}{|c|c|}
\hline \multicolumn{2}{|c|}{ Table \& Figure 5 } \\
\hline $\begin{array}{c}\text { Have you faced any physical } \\
\text { harassment in the line of your duty? }\end{array}$ \\
\hline \multicolumn{2}{|c|}{ Frequency } \\
\hline Yes & 22 \\
\hline No & 65 \\
\hline \multicolumn{2}{|c|}{ N $=87$} \\
\hline \multicolumn{2}{|c|}{ No answer $=8$} \\
\hline \multicolumn{2}{|c|}{ Total=95 } \\
\hline
\end{tabular}

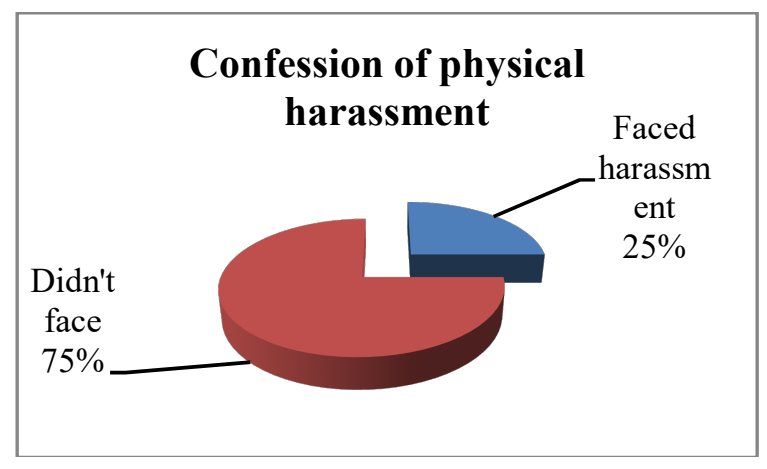

Interpretation: Table \& Figure 5 denotes that the content of physical harassment also exists in media in Sindh and that is very drastic though $75 \%$ respondent affirmed that they have not faced but $25 \%$ of the respondent confessed that they have met with physical harassment in the field for journalistic work. The state of affairs is not good and need to be considered for any action in the lines of the improvement of media environment in the province. The condition for women journalists is more drastic and urges prompt measure to meet the international standards of working environment.

\section{Conclusions}

The findings of the study give a clear picture of the existence of discrimination in the media industry in the province of Sindh, Pakistan. Twenty two percent of the respondents confessed that they have faced discrimination while $39 \%$ of the respondents affirmed that they have observed discriminative behaves in the media in the province. The results further confirm that gender discrimination also exists in the media in the province of Sindh and $23 \%$ of the respondents affirmed its presence. These statistics prove the Hypothesis No.1: Gender discrimination exists in media in the province of Sindh, Pakistan.

Results regarding the threats to journalists prove that the content of threat prevails in the sphere of media in the province of Sindh. The findings show that journalists are facing threats for their journalistic work as $39 \%$ of the respondents confessed that they have faced threats in their field. These statistics prove the Hypothesis No2: Journalists are facing threats in the field while performing their professional duties in Sindh. 
The study extracts some other interesting results that indicate alarming situation regarding the existence of discrimination based on language $32 \%$, on the basis of political thoughts $17 \%$, on the basis skills and experience $9 \%$, on the basis of religion $7 \%$ and on the basis of social status, economical status and educational level $4 \%$ each. These statistics reveal a very drastic scenario of the media industry in the province. The racial discrimination affirmed by $32 \%$ of the respondents tops the rests and indicates that racial streaming is prevailing in the fourth pillar of the government. This situation is shocking for democracy and federalism. The third extreme that the study finds is discrimination on the basis of political thoughts as $17 \%$ of the respondents pointed out its existence. This portrays that the media in Sindh is highly involved in political activities and that corrupts the professionalism, impartiality and objectivity of the press which are the fundamental prospects the industry. The presence of discrimination based on religious thoughts and philosophies is the fourth extreme found by the study as $7 \%$ of the respondents affirmed that they have observed discrimination on the basis of religion in the media landscape of the province. This aspect of the media in Sindh illustrates religious extremism in the industry which needs prompt measures to be balanced.

\section{Further Research}

Most of gender based studies in Pakistan are focused on the stereotyping behavior and social and economical issues. The impotence of the problems is recognized but gender discrimination in the workplace especially in the media industry and its association with threats is of vital importance. Media as a watch-dog and opinion making institution needs more participation of women as journalists because women journalists can effectively advocate the gender based issues as a part of the stage but threats in general and linked with gender are the blocking agents for women to enter the field of journalism. This study will open discussion for the need of more study about gender discrimination and its connections with threats in the media industry in Pakistan.

\section{Recommendations}

The study finds that issues related to gender discrimination are in critical position in the media industry of Pakistan. The presence of discrimination and the factor of sexuality in the industry are alarming. The difference in salary packages on the basis of gender is the worst indicator of inequality in media market. The unbalanced working environment and security risk need affirmative discrimination. Measures on national and institutional level should be taken to diminish the stereotyping in media and enhance women's participation in the mushrooming media market in the country. Awareness campaigns should be devised and launched to advocate the importance of women and gender equality. The lack of literature and surveys regarding the issues of gender discrimination in media is shocking. The situation calls for consistent research to explore gender discrimination and its connection with threats to journalists in Pakistan. 
The roots that nurturing gender discriminations like unjustified cultural practices based on unethical beliefs should be properly dismantled and lessons should be included in text books to advocate gender equality in the new generation. Laws and regulations should be framed to raise the status of women and provide legal protection to encourage them to participate in the economic market. This will not only develop the position of females but will also enhance the total production capacities of the state.

Skill development, special education, self defense training and other supportive programs should be initiated to enable women to combat the hindrances in the field as well in usual life cycle. To achieve equality and demolish the relics of gender discrimination will require changes in attitudes, relationships, legal frameworks, institutions, decision making structures and social and economical models of individual and collective livings.

Safety measures should be devised and a proper dialogue mechanism should be scheduled among the all the stake holders to protect journalists and ensure the free of fear media environment in the province. Only in this way professional journalism is possible and the international standards can be achieved.

\section{References}

Abbas, Dr., Qaiser, Hameed, Abdul \& Waheed, Aamer (2011). Gender Discrimination \& its Effect on Employee Performance/ Productivity. International Journal of Humanities and Social Science, vol.1, p.15.

Abbasi, Khursheed (2018, September 27). Personal Interview. Karachi Press Club, Karachi.

Adu, Oppong \& Arthur, Cecilia (2015). Gender Discrimination in the Workplace: A Study of Women's Participation in Higher Education Management in Ghana. Afro Asia Journal of Social Sciences, vol.3, pp.1-15.

APNS (2018). All Pakistan Newspapers Society: Official Site. Retrieved on March 26, 2018 from: https://apns.com.pk

Bano, Sheher (2018, September 23). Personal Interview. Office of Daily The News International, Karachi.

CPJ (2018). Retrieved on March 24, 2018 from: https://cpj.org/2015/04/attacks-on-thepress-more-freelancers-less-support-greater-danger.php.

Durani, Tariq (2018, October 12). Personal Interview in Larkana Press club, Larkana. 
F.H (2018). Freedom House: Press Freedom Annual Report. Retrieved on March 25, 2018 from: https://freedomhouse.org/report/freedom-world/2018/pakistan.

Faran, Imtiaz (2018, September 18). Personal Interview. Office of TV One, Karachi.

Fareed, Dr., Arfa (2000). Post Modernism. Karachi. University of Karachi Press

Georgellis \& Wall (2004). Gender Difference in Self-Employment, Federal Reserve Bank of Saint Louis, Working Paper 00187.

GMMP (2010). Retrieved on March 24, 2018 from: http://cdn.agilitycms.com/whomakes-the-news/Imported/reports_2010/highlights/highlights_en.pdf

GMMP (2015). Retrieved on March 24, 2018 from: http://cdn.agilitycms.com/whomakes-the-news/Imported/reports_2015/global/gmmp_global_report_en.pdf

Hamid Sheikh (2018, October 10). Personal Interview in Hyderabad Press Club.

Hearn, J. \& Parkin, W. (1987). Sex at Work: The Power and Paradox of Organizational Sexuality. Saint Martin's Press. Network. , pp.20-24.

Isbah (2018, September 15). Personal Interview. Office of Daily Awam, Karachi.

Jayachandran, Seema (2015). The Roots of Gender Inequalities in Developing Countries. Retrieved on March 22, 2018, from: http://faculty.wcas.northwestern.edu/ sjv340/roots_of_gender_inequality.pdf

Khanzada, A.H (2018, September 25). Personal interview. Office of Neo TV, Karachi.

King, Angela (2002). Gender Mainstreaming: An Overview. Retrieved on March 25, 2018 from: http://www.un.org/womenwatch/osagi/pdf/e65237.pdf

KPC (2018). Official Site Karachi Press Club. Retrieved on March 24, 2018 from: http://karachipressclub.com/

Kumar, V., N., Mathialagan, P. \& Sabarathnam (2016). Developing Guttmann Scale for Measuring Degree of Empowerment of Rural Women. International Journal of Applied Research, vol.2:3, pp.195-201

Latif, Amir (2018, September 20). Personal Interview. Karachi Press Club, Karachi. 
Le-Anth, T. (2002). The Difference of Immigrant Self-Employment. The International Migration Review, vol.34:1.

Matias, J., Nathan \& Wallach, Hanna (2015). Working Paper: Modeling Gender Discrimination by Audiences of Online News. Retrieved on March 23, 2018 from : http://cj2015.brown.columbia.edu/papers/gender-discrimination.pdf

Miller (2010). Contraception as Development New Evidence from Family Planning in Colambia. Economic Journal. Vol. 120, 36.

Morna, Lowe, Collen (2002). Promoting Gender Equality in and Through The Media: A Southern African Case Study. EGM/Media/2002/EP.5 Retrieved on March 22, 2018 from: http://www.un.org/womenwatch/daw/egm/media2002/reports/ EP5Morna.PDF

Nasir, Muhamamd (2018. September 19). Personal interview. Office of Daily The News International, Karachi.

Oppong \& Arthur, Cecilia (2015). Gender Discrimination in the Workplace: A Study of Women's Participation in Higher Education Management in Ghana. Afro Asian Journal of Social Sciences, vol.3, Quarter 3, 2015. Retrieved on March 18, 2018, from : http://www.onlineresearchjournals.com/aajoss/art/180.pdf

Reeves, Hazel \& Sally, Baden (2002). Gender and Development: Concept and Definitions. Retrieved on March 22, 2018, from: http://www.bridge.ids.ac.uk/ sites/bridge.ids.ac.uk/files/reports/re55.pdf

Shahid, Akram (2018, October 10). Hyderabad Press Club, Personal Interview in Hyderabad.

Sharda, Adhikari (2014). Media and Gender Stereotyping: The need for Media Literacy. International Research Journal of Social Sciences, vol.3:8, pp.43-49.

Sofi, Athar, Javid (2018, September 21). Personal Interview. Office of Daily Awam, Karachi.

UNESCO (2009). Gender Equality and Women's Empowerment.

United Nations (1994). Declaration on the Elimination of Violence against Women. Retrieved on March 22, 2018, from: <http://daccess-ddsny.un.org/doc/UNDOC/ GEN/N94/095/05/PDF/N9409505.pdf? 
Vogt, W. P. (1999). Dictionary of Statistics and Methodology: A Nontechnical Guide fo the Social Sciences. London: Sage.

W.S. (2009). World Survey on the Role of Woman. Retrieved on March 25, 2018 from: http://www.un.org/womenwatch/daw/public/WorldSurvey2009.pdf

Wood, T., Julia (n.d). Gendered Media: The Influence of Media on Views of Gender. Retrieved on March 22, 2018 from: https:/www.nyu.edu/classes/jackson/ causes.of.gender.inequality/Readings/Wood\%20-\%20Gendered $\% 20 \mathrm{Media} \% 20$ \%2094.pdf

Zaheer, Romana, Hussain, Sanam \& Nadeemullah, Muhammad (2018). Agricultural Development and the Role of Women's Self-Employment in Pakistan. Pakistan Journal of Gender Studies, vol.16, pp.103-121.

Fazal Hussain is Ph.D Student in the Department of Mass-Communication, Federal Urdu University Karachi. 